\title{
肝切除術後の高ビリルビン血症の病態 一胆汁中ビリルビン亜分画分析とその意義一
}

\begin{tabular}{|c|c|c|c|c|c|c|}
\hline \multicolumn{7}{|c|}{ 山形大学第 1 外科 } \\
\hline 石山 秀一 & 布施 & 明 & 田中 & 丈二 & 浦山 & 雅弘 \\
\hline 五十嵐幸夫 & 須藤 & 幸一 & 平井 & 一郎 & 塚本 & 長 \\
\hline
\end{tabular}

肝切除術後の黄疸の病態を解明するために胆汁中のビリルビン亜分画を高速液体クロマトグラ フィー法にて分析した. 胆道癌切除21例のうち非肝切除 8 例を対照群, 肝切除例で術後 2 週後にも血 清総ビリルビン值が $2 \mathrm{mg} / \mathrm{dl}$ 以下にならなかった 5 例を黄疸群, その他 8 例を非黄疸群とした. 胆汁は 胆汁外瘻より経日的に採取した。術後 3 群とも第 1 日目に bilirubin diglucuronide (BDG) が減少し, それに対応して bilirubin monoglucuronide monoglucoside および monoxyloside (BGG+BGX) が 増加した.この変化の大きさは対照群く非黄疸群く黄疸群で, 対照群, 非黄疸群では 5 ～ 7 日目には ほぼ術前值に復したが黄㾝群では 2 週後にも有意の差を示した．抱合醅素の異常あるいは基質の変化 によって, BDG からより親水性の弱い BGG + BGX の割合が増加するために肝細胞膜からの分泌輸 送が阻害され, 黄疸が遷延するものと考えられた。ビリルビン亜分画は肝切除術後黄疸の病態把握に よい指標となりうると思われた。

Key words: hyperbilirubinemia, bilirubin conjugates, hepatectomy, bile duct cancer, high performance liquid chromatography

\section{はじめに}

肝門部胆管癌あるいは進行胆囊癌の根治手術は，そ の浸潤様式および肝門部の解剖学的特性から広範肝切 除術を必要とすることが多い，広範肝切除術の安全性 は向上しつつあるが,いまなお術後の高ビリルビン(以 下, Bil と略記)血症にしばしば遭遇し，そのまま肝不 全に移行することがある。この術後黄疸についての研 究は古くから行われてきたが，その詳細はいまだ明ら かではなく対策も確立していない. 著者らはこの肝切 除術後の高 Bil 血症の病態を解明するために, 胆道癌 に対する肝切除術後に経時的に胆汁の Bil 亜分画分析 を行い以下の知見を得た。

\section{対象および方法}

\section{1. 対象}

対象は胆道癌切除21例である。そのうち下部胆道癌 （Vater 乳頭部癌 2 例を含む）で膵頭十二指腸切除を 行った 6 例抢よび胆翼癌で拡大胆囊摘出術を行った 2 例の計 8 例を対照群とした. 他の13例は肝門部胆管癌

$<1995$ 年 9 月13日受理 >別刷請求先: 石山 秀一 干990-23 山形市飯田西 2 丁目 $2-2$ 山形大学医学 部第 1 外科
で肝切除を行った症例（以下, 肝切除群と略記）であ る. この肝切除群13例のうち, 術後14日を経過しても 血清総 Bil 值（以下，T-Bil と略記）が $2 \mathrm{mg} / \mathrm{dl}$ 以下に ならなかった 5 例(肝 $\mathrm{S}_{1-4-5}$ 切除：1, 拡大肝葉切除 4 例) を黄疸群, 他の 8 例(肝 $\mathrm{S}_{1-4-5}$ 切除 2 , 拡大肝葉切 除 6 例) を非黄疸群とした。

なお, 術前閉塞性黄疸を呈した症例は経皮経肝胆道 ドレナージ（以下，PTBD と略記）を行い，滅黄をは かって手術を行ったので術前 T-Bil 值は21例全例2.0 $\mathrm{mg} / \mathrm{dl}$ 以下であった。 また, 術後に, 少なくとも画像 診断で胆道の閉塞性機転を疑わせた症例はいなかつ た.

術前 PTBD を行った症例は対照群 4 例, 肝切除群 12 例であった。これらの症例で PTBD tubeより術前に 採取した胆汁の細菌培養は対照群では 3 例, 肝切除群 では12例に陽性であった。細菌培養陽性の症例の術後 のドレインからは， $1 \sim 2$ 週間，胆汁培着で同定され た菌が検出されたが，全症例で特に外科的処置の必要 なほどの膿瘍形成はみられなかった。

2. 胆汁の Bil 亜分画分析

術前は PTBD tube, 術後は手術中に挿入した胆汁外 
瘦 tube より経日的に胆汁を採取した。胆汁は採取後た だちに氷冷し遮光した。

胆汁の亜分画分析はYamashita ら ${ }^{1)}$ 方法に準じ て行った.すなわち,まず採取した胆汁に最終濃度 $4 \%$ となるように ascorbic acidを加えた後, 胆汁に対し て3 倍量の acetone を加えて Bil を抽出した。これを $1,800 \mathrm{~g}$ で 5 分間遠心した後, その上清に対して 4 倍量 の.1M sodium acetate 液を加光, Millex SR filter $(0.5 \mu \mathrm{m}$, Milipore, Bedford, MA, USA)を用いて 濾過した。この濾過液の $20 \sim 80 \mu 1$ を高速液体クロマト

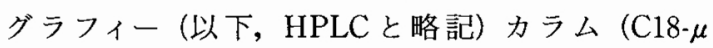
Bondapak column, $30 \times 3.9 \mathrm{~mm}$ i.d., Waters, Milfor$\mathrm{d}$, MA, USA) にかけ, 移動相として $0.5 \mathrm{mM}$ pentanesulphonate を含む0.1M sodium acetate $(\mathrm{pH}$ 4.0)と acetonitorile 用いて逆相 HPLCを行った. 分析時間は60分で, acetonitrile 濃度を 0 〜35分で 20〜48\%，35〜45分で48〜 90\%の gradientをかけ，残 りの 10 分は $90 \%$ で維持して $450 \mathrm{~nm}$ の吸光度でモニ ターした.

\section{3. 統計学的処理}

平均值は平均值士標準誤差值で表示し，3群間の検 定にはFisherのPLSD テストを用いて, $\mathrm{p}<0.05$ を有 意差ありとした。

\section{成 績}

\section{1. 血清 T-Bil 值の推移}

血清 T-Bil 值は 3 群とも術後第 1 日目に上昇した。 対照群, 非黄㾝群ではその後, 徐々に正常化したが黄 疸群では14日目以降も高 Bil 血症が続いた（Fig. 1).

2. 胆汁中 Bil 亜分画の変動

1) 対照群, 術前の胆汁中 Bil 覀分画分析パターン： 対照群症例 (61歳, 男性. 下部胆管癌症例), 術前の胆 汁中 Bil 严分画は 5 つの主ピークを示した (Fig. 2).

これらの分画は親水性の高い順に, bilirubin diglucuronide (以下, BDG と略記), bilirubin monoglucuronide monoglucoside (以下, BGG と略記), bilirubin monoglucuronide monoxyloside (以下, BGX と略 記), 2 種の bilirubin monoglucuronide (以下, BMG と略記 ; endovinyl, $\mathrm{C}_{8}$, および exovinyl, $\mathrm{C}_{12}$ ) に相 当する ${ }^{1)}$ (Table 1). BGG と BGX, BMG の endovinyl および exovinyl はときに明確に分画することが不可 能であったので，以下これらの主ピークを BDG， $\mathrm{BGG}+\mathrm{BGX}, \mathrm{BMG}$ の 3 群にわりて検討した.

2）胆汁中 Bil 覀分画の変動

(1) 症例
Fig. 1 Postoperative changes in serum total bilir. ubin

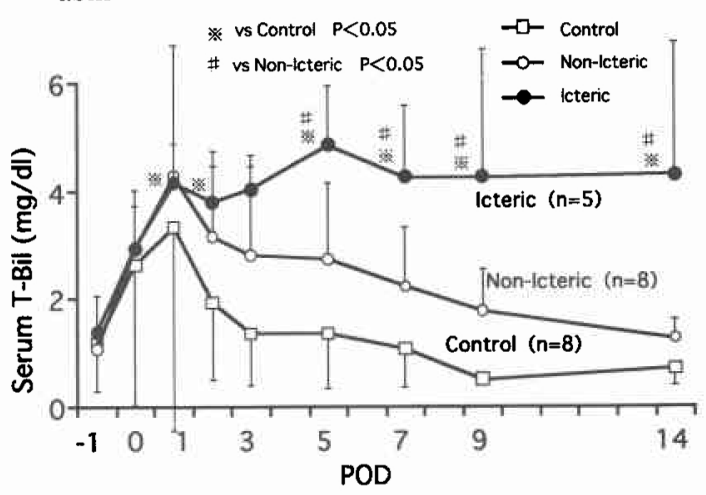

Fig. 2 Preoperative bile bilirubin subfractiona. tion by HPLC in the 61-year-old male patient with lower bile duct cancer

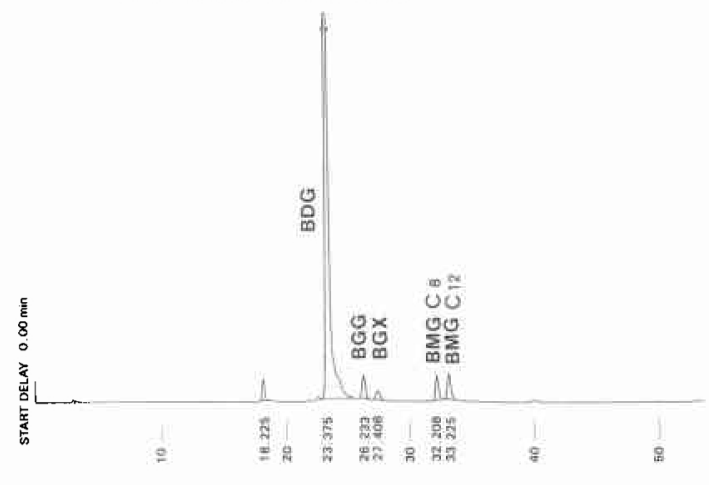

Table 1 Bilirubin subfraction

1 Bilirubin Diglucuronide (BDG)

2 Bilirubin Monoglucuronide Monoglucoside (BGG)

3 Bilirubin Monoglucuronide Monoxyloside (BGX)

4 Bilirubin Monoglucuronide (endovinyl) ( $\mathrm{BMG}_{8}$ )

5 Bilirubin Monoglucuronide (exovinyl) ( $\mathrm{BMG} \mathrm{C}_{12}$ )

（1）対照群：61歳, 男性. 下部胆管癌にて膵頭十二 指腸切除術を行った。術後第 1 日目に軽度の血清 Bil 值の上昇を認め, 約 10 数\%の BDG の減少, BGG+ BGX の増加を見たが， 3 日目には正常に復した(Fig. 3).

（2）黄疸群(1)：76歳, 男性. 肝門部胆管癌にて拡大 右葉切除術を行った. 血清 T-Bil 值が術後第 1 日目に $5.3 \mathrm{mg} / \mathrm{dl}$ に上昇し, 第 12 日日には $10.1 \mathrm{mg} / \mathrm{dl}$ まで上 昇した. BDG は第 1 日目に術前の73.3\%から $46.7 \% に$ 減少し, その後も低值で推移した。これに対応して 
Fig. 3 Postoperative changes in bile bilirubin subfractions in the 61-year-old male patient of control group after pancreatoduodenectomy for distal bile duct cancer

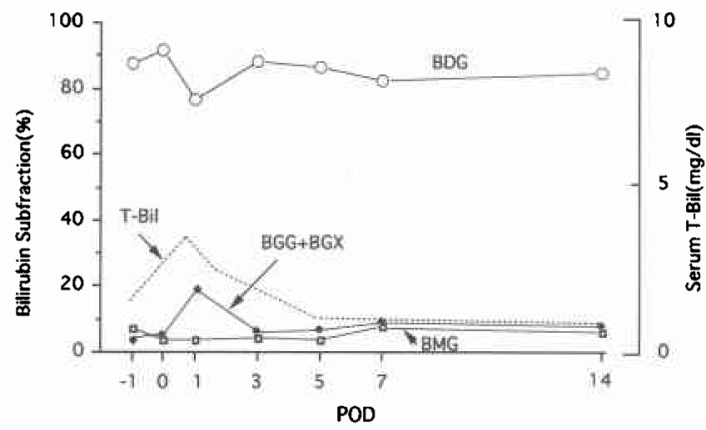

Fig. 4 Postoperative changes in bile bilirubin subfractions in the 76-year-old male patient of icteric group after extended hepatic lobectomy for prox. imal bile duct cancer

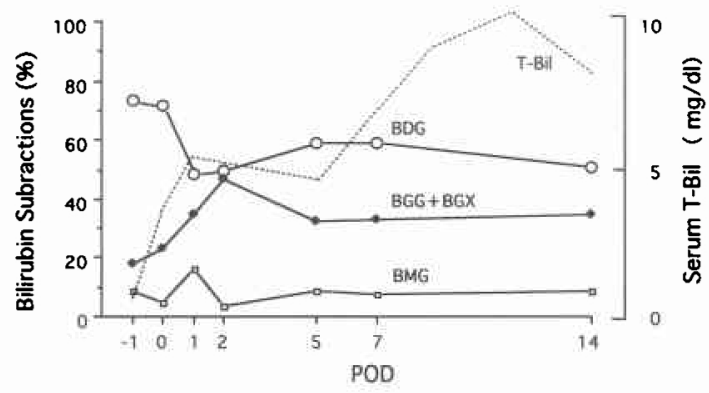

BGG+BGX が増加し高值が持続した. BMG は第 1 日目に軽度の上昇を示したのみであった，本症例は 12 日目より predonisolone, prastaglandin $\mathrm{E}_{1}$ を投与した が, 血清 T-Bil 值が正常化するのに約 2 か月を要した (Fig. 4).

（3）黄㾝群(2)：77歳, 男性. 肝門部胆管癌で $\mathrm{S}_{1-4-5}$ 切 除を行った。術前, 術後第 1 日目, 第 5 日目の chromatographを示す (Fig. 5). BDGが術前の $81.4 \%$ 加第 1 日目には $38.3 \%$ 著明に滅少, BGG十 BGX が7.2\%から $48.2 \%$ に増加した．血清 T-Bil 値は 第 1 日目に $3.5 \mathrm{mg} / \mathrm{dl}$, 第 5 日目に $6.5 \mathrm{mg} / \mathrm{dl}$ に上昇し たが，5日目の胆汁中 Bil 覀分画は BDG；60.4\%， $\mathrm{BGG}+\mathrm{BGX} ; 27.1 \%$ 改善傾向にあったため経過を 観察したところ, 15日目には血清 T-Bil 值が2.5mg/dl となった。

(2) 各群における胆汁中 Bil 业分画の変動
Fig. 5 Perioperative changes in bile bilirubin subfractionations in the 77 year-old male patient performed $\mathrm{S}_{\mathrm{i}-4-5}$ subsegmentectomy for proximal bile duct cancer
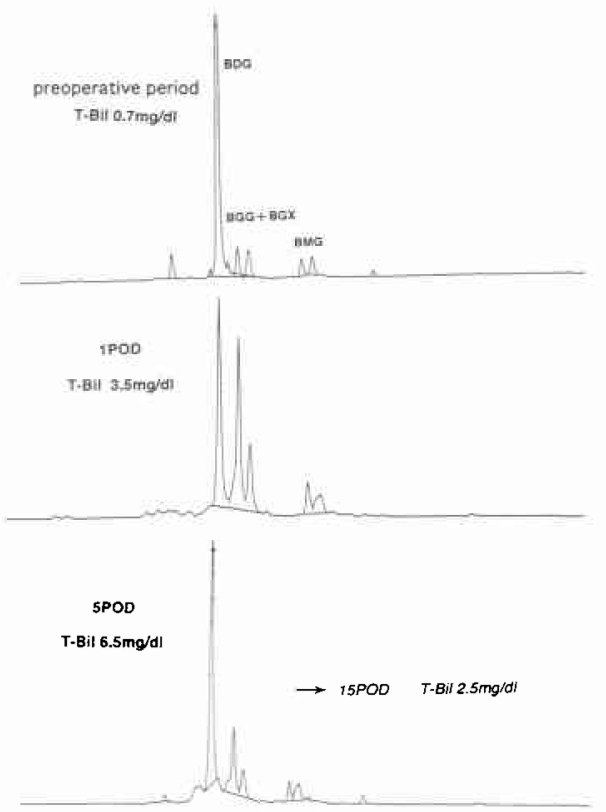

Fig. 6 Postoperative changes in BDG

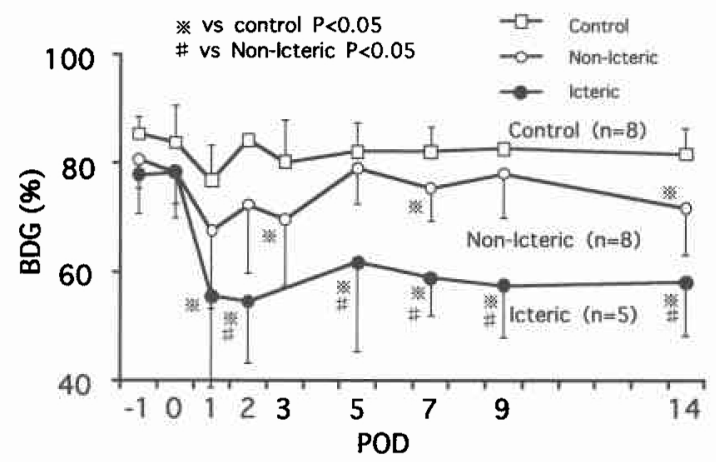

(1) BDG の変動：術前値は対照群85.3土3.0, 非黄 㾝群 $80.6 \pm 5.3$, 黄疸群 $77.8 \pm 7.2 \%$ で有意差はないが 黄疸群で低い傾向があった。術後第 1 日目には 3 群と も BDGが減少した（対照群；76.8土6.4, 非黄疸群 ; $67.4 \pm 14.3$, 黄疸群 ; $55.4 \pm 16.6 \%$. 対照群 vs 黄㾝群, $\mathrm{p}<0.05)$. 対照群では 2 日目には術前値に回復し, 非 黄㾝群でも 5 日目には回復傾向にあったが, 黄疸群で は低值が持続し第14日目にも有意な低值を示した (Fig. 6).

(2) $\mathrm{BGG}+\mathrm{BGX}$ の変動: $\mathrm{BGG}+\mathrm{BGX}$ の術前值は 
Fig. 7 Postoperative changes in $\mathrm{BGG}+\mathrm{BGX}$

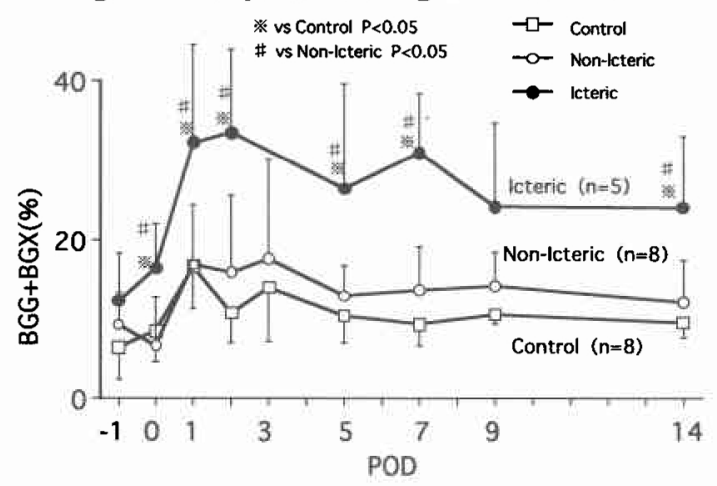

Fig. 8 Postoperative changes in $\mathrm{BMG}$

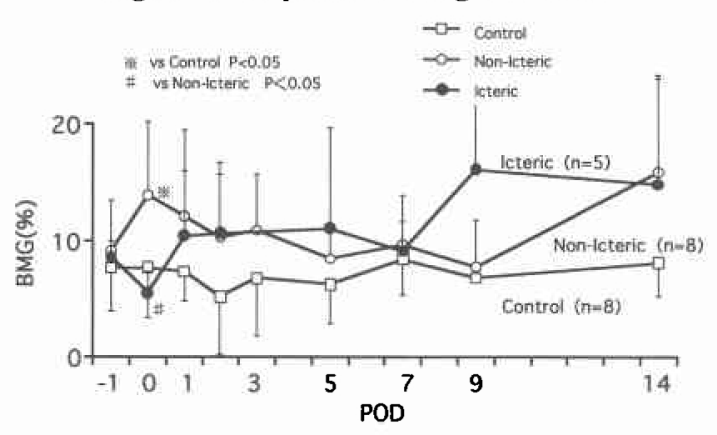

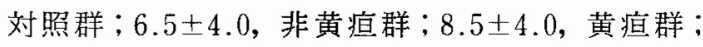
$12.3 \pm 6.0 \%$ で有意差はないものの, 黄疸群で高值で あった. 対照群, 非黄疸群の術後の変動は軽度であっ たが, 黄㾝群では第 1 日目から 2 日目にかけて高值(第

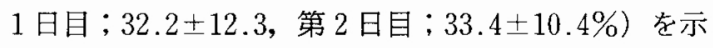
し，以後14日目まで有意な高値が持続した(Fig. 7).

(3) $\mathrm{BMG}$ の変動: $\mathrm{BMG}$ は術前值に各群で差はな く一定の有意な変動を認めなかった（Fig. 8).

\section{考察}

肝門部胆管癌や進行胆囊癌では手術の根治性を保つ ために広範肝切除が必要となることが多い. 肝切除は 近年, 安全な手術手技として確立し, その適応範囲も 拡大されてきた。しかしながら，いまなお術後の高 Bil 血症に遭遇することがしばしばであり，ときにそのま ま肝不全に移行することがある、肝炎や過大侵襲によ る絶対的な機能的肝細胞量不足が原因となる肝不全で も高 Bil 血症を呈するが，これは間接 Bil の上昇が特 徵的で, 通常みられる肝切除術後の高 Bil 血症とは性 質が異なるように思われる。この肝切除術後の高 Bil 血症については古くから研究されてきたが, 発生機序
やその対策についての詳細はいまだ不明である。

われわれは胆道癌に対する肝切除術後の胆汁中 Bil 悪分画分析を行うことにより, 肝切除術後に胆汁中の Bil 組成が変化することを明らかにした。高 Bil 血症が 遷延した症例では術前より BDGが低值を示す傾向が あり，かつ術後にはより著明な減少を示した.このと き，この BDGの減少に対応するように BGG+BGX が増加していた。すなわち, 胆汁中の Bilのうち2 個の グルクロン酸 (以下，GA と略記）を持つ BDG が減少 し, 1 個の GA と glucose, あるいはxylose が結合し た BGGや BGX が増加しており, 胆汁中の Bil は親水 性の高いものから低いものへ，割合が変化していた。

胆汁中の Bil 覀分画を行うと, ヒトでは通常, 抱合さ れた Bil がほとんどで，なかでも BDG が圧倒的に多 く約 $80 \%$ 占める. BGG+BGX と BMG はそれぞれ $10 \%$ 程度で非抱合型の Bil はほとんど検出されない $(1 \% \text { 前後 })^{2)}$. Bil は肝細胞のミクロソームで GA 抱合 をうけた後, 肝練胞外に分泌輸送されるが, 細胞膜通 過には GA 抱合が不可欠である。これはGA 分子が細 胞膜に存在する特異的な担体に結合するためか, ある いは抱合によって内因性の水素結合が壊されることに より，親水性の陰イオンに親和性をもつ担体系に輸送 されやすくなるからだと言われている゙).

いずれにせよ，細胞膜に存在する担体によって細胞 膜を通過するためにはより親水性が高く, GA 分子 2 個を有する BDG が, BGG や BGX よりも有利である と考えられる。したがって, BDGが減少し, BGG+ BGX が増加すると肝細胞からの Bil 輸送が障害され, 高 Bil 血症が惹起される可能性が高く,これが肝切除 術後の高 Bil 血症の原因であると考えられる．肝切除 術後の高 Bil 血症に扔いて，胆管閉塞がないにもかか わらず，直接 Bil が優位な高 Bil 血症がしばしばみら れることはこの推論を裏づけるものであると思われ る.

BilのGA 抱合反応はUridine diphosphateglucuronosyl transferase (以下, UDP-GT と略記) の触媒の下にUridine diphosphate-glucuronic acid (以下, UDP-GA と略記) を基質として行われる ${ }^{4)}$. し たがって，肝切除術後の胆汁中 Bil 悪分画異常の原区 は，この反応を触媒する酵素であるUDP-GT の異常 か，基質の変化によるものと想定される.

UDP-GT はミクロソームの内膜に局在する膜結合 性タンパクである. UDP-GT とミクロソーム脂質膜と は密接に関係しており，phospholipaseで処理すると 
活性が低下する.また, UDP-GA 濃度にも影響をうけ， 非抱合型 Bil や BMG を基質とした場合, BDG の産生 は UDP-GA の濃度上昇とともに増加することが知ら れている5.

広範肝切除術後の残肝機能の障害の原因のひとつと して循環障害あるいは再灌流障害による膜の障害があ げられる.膜の障害がおこって膜脂質の integrity がそ こなわれると, UDP-GT の活性が阻害されることは容 易に推察される。

一方, UDP-GA はUDP-glucoseを基質にUDPglucose dehydrogenase の作用によって生成される が,この反応には $\mathrm{NAD}^{+}$補酵素として必要とする。 一般に GA 抱合を阻害する物質として, エ夕ノール, 乳酸、ソルビトールなどがあげられており,これらの 物質はすべて細胞内の $\mathrm{NAD}^{+}$pool を隇少させるもの である ${ }^{6)} . \mathrm{NAD}^{+}$の減少はこれらの物質の作用のみな らず, 細胞内の ATP/ADP 比, あるいは energy charge を低下させる要因があればいかなることに よってもおこりうる゙.

肝切除術後に残肝の energy charge が低下すること はよく知られており，その原因のひとつは機能的肝細 胞数の減少と旺盛な肝再生によるとされている8 . ま た, 門脈圧え進によって肝血流量が減少すると energy charge の低下, $\mathrm{NAD}^{+}$pool の減少が㧍こる. Adachi ら`はラットを用いた実験で上腸間膜静脈の一時的な 閉塞によって肝内の UDP-GA 濃度が低下することを 示し, Kamisako ら ${ }^{(0)}$ は Salicylamide 投与による UDP-GA の減少によって胆汁中 Bil 亜分画の異常が 起こることを示した。

一方, 閉塞性黄疸症例では胆汁の細菌感染の頻度が 高く, 術後の Bil 亜分画の変化も細菌の影響をうけて いる可能性が考えられる. しかし, 今回の症例のうち 肝切除群で PTBD を行った症例全例で胆汁中細菌培 養が陽性であり, 術後に洼黄疸群, 非黄疸群ともドレ インの排液から胆汁培養で同定された細菌が検出され た, したがって, 細菌感染だけでは両群間の違いを説 明できないため，な険討が必要である.

これらの事実を総合すると, 肝切除術後にはUDP. GT の活性を変化させたり, UDP-GA の生成を阻害す る因子が種々ある。これらが単独, あるいは複数で作 用することによって, 胆汁中の Bil 亜分画に異常がお こり, 高 Bil 血症が薏起されるものと考えられる.

この Bil 亜分画の異常は Fig. 5 の症例にみられる ように血清 T-Bil 值の変化に先だってみられる傾向が
あり,また,この異常が持続すると高 Bil 血症も持続し た.したがって, 胆汁中 Bil 亜分画の分析は術後高 Bil 血症の重症度, あるいは治療効果判定の指標としても 有用である可能性がある。

以上, 肝切除術後の胆汁中 Bil 覀分画分析を行って 肝切除後の高 Bil 血症の病態について考察した。 本研究は厚生省がん助成金の援助をうけた。 本研究の要旨は第46回日本消化器外科学会総会 (福井) で 発表した.

\section{文献}

1) Yamashita $M$, Adachi $Y$, Yamamoto $T$ : Analysis of bilirubin conjugates in human bile by column liquid chromatography. J Chromatogr 375:386-391, 1986

2) Yamashita $M$, Adachi $Y$, Yamamoto $T$ : Analysis of bilirubin conjugates in human bile by column liquid chromatography-Changes in their composition in hepatobiliary disease. J Gastroenterol Hepatol 2: 181-190, 1987

3) Billing HB: Bilirubin metabolism. Edited by Schiff L, Schiff ER. Diseases of the liver. 6th edition. Lippincott, Philadelphia, 1987, p103127

4) Jansen PLM, Mulder GJ, Burchell B et al: New developments in glucuronidation research: Report of workshop on "Glucronidation, its role in health and disease". Hepatology $15: 532--544,1992$

5）神坂和明, 古要俊也, 上杉孝：肝 UDP グルクロ ニルトランスフェラーゼと抱合. 肝・胆・膵 17 ： 201-206, 1988

6) Moldeus $P$, Andersson $B$, Norling A: Interaction of ethanol oxidation with glucuronidation in isolated hepatocyte. Biochem Pharmacol 27 : 2583-2588, 1978

7) Aw TY, Jones DP: Secondary bioenergetic hypoxia. J Biol Chem 257 : 8997-9004, 1982

8）小澤和惠：ミトコンドリアから肝缄外科へ.メデ イカルトリビューン, 東京, 1989

9) Adachi $Y$, Kamisako $T$, Yamamoto $T$ : The effects of temporary occlusion of the superior mesenteric vein or splenic vein on biliary bilirubin and bile acid excretion in rats. J Lab Clin Med 118:261-268, 1991

10) Kamisako $T$, Adachi $Y$, Yamamoto $T$ : Effect of UDP-glucuronic acid depletion by salicylamide on biliary bilirubin excretion in the rat. J Pharmacol Exp Ther 254:380-382, 1990 


\section{Pathogenesis of Hyperbilirubinemia after Major Hepatectomy -Analysis of Bile Bilirubin Subfractionations by High Performance Liquid Chromatography-}

Shuichi Ishiyama, Akira Fuse, Joji Tanaka, Masahiro Urayama, Yukio Igarashi, Koichi Sutoh, Ichiro Hirai and Masaru Tsukamoto

The First Department of Surgery, Yamagata University, School of Medicine

In order to investigate the pathogenesis of hyperbilirubinemia after major hepatectomy, we studied 21 patients with biliary tract cancer. Those patients were divided into three gruops: a non-hepatectomy control group $(n=8)$, and non-icteric $(n=8)$ and icteric $(n=5)$ hepatectomy groups. In the icteric group, the serum bilirubin level was above $2.0 \mathrm{mg} / \mathrm{dl}$ even two weeks after surgry. Bile bilirubin subfractionations were analyzed by HPLC. The proportions of bilirubin diglucuronide (BDG) decreased on the first postoperative day in all three groups, whereas those of bilirubin monoglucuronide monglucoside (BGG) and monoxyloside (BGX) increased. The grade of this abnormality was most severe in the icteric group among the three groups. In the icteric group, these changes were kept at significant levels compared with both the control and non-icteric groups. These changes could cause difficulty in bilirubin transport across the cell menbrane of hepatocytes so that hyperbilirubinemia might occur after major hepatectomy. The analysis of bile bilirubin subfractionations seemed useful for the evaluation of hyperbilirubinemia after major hepatectomy.

Reprint requests: Shuichi Ishiyama First Department of Surgery, Yamagata University School of Medicine

2-2-2 Iida-Nishi,Yamagata, 990-23 JAPAN 